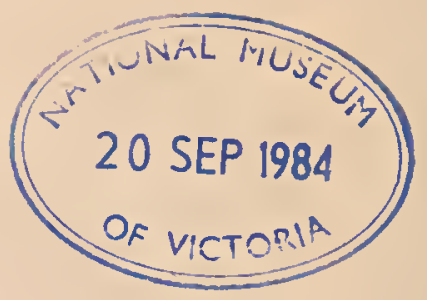

\title{
DEPARTMENT OF MINES.
}

ISSUED BY

\author{
MHES TRAVIS, ACTING SECRETARY FOR MINES, UNDER THE AUTHORTTY OF \\ THE ION. HENRY FOSTER, M.P., MINISTER OF MINES.
}

\section{REPORT UN LONG TUNNEL MINE AT REEDY CREEK.}

\section{(By W. Forbes, ex-Assistant Geological Surveyor.)}

I have the honour to report that I liave examined the Long Tunnel Company's mine at Rcedy Creek as instructed.

The rocks are of Upper Silurian order, and eomprise yellowislı sandstones and mudstones at thé surfnec: in the tumel tho hed consist of fine-grained grey sandstones with narrow beds of black and bluish coloured slates for 300 feet. From 300 feet to 400 feot the beds consist of grey sandstone with fine slate beds, and are traversed lyy quartz spurs; the remainder cousists of dark-bluisli slite.

The strike of the loels in this mino is $\mathrm{N} .75^{\circ} \mathrm{W}$, and dip from $43^{\circ}$ to $50^{\circ} \mathrm{S}$. W. The genernl pitch of tho rocks is $18^{\prime \prime}$ S. Fi

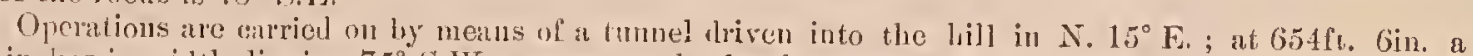
reef 3 inches in wilth dipping $75^{\circ} \mathrm{S}$. W. Was cut, and a level driven on it in a south-ensterly direction; a little goll has heen seen in this recf. Thompson's recf worked so profitably some years ago firom the top of the litl to 2,50 fect was intersecter below the old workings at $713 \mathrm{ft}$. Gin. by this tmmel. The reef lips $64^{\circ} \mathrm{K.W}$. for 25 feet above the level of the tnunel, above that it raries from rertical to a slight sonth-wost dip; the reef averages 9 inches to 2 inches in width. The present compatny's operations are confined to this recf and the country tio the north. An unticlinal fold oceurs betwe these two reefs. At this level 'Tlompson's reef passes through castern gromnd consisting of dark-bhinish slate, containing pyrites and traversed by quartz spurs or leaders, parallel to one anotlicr in a northerly direction across the clearage plancs from the man reef; in width from 1 inch to a mere thread, all of which eonton coarse goll. From an examination of many specimens I could not find any gold in the slate; it appears he contaned in the quartz spurs, threals, and the recf; in the slate nodules of fine-grained sandstonc ocentr from $\frac{1}{8}$ incl to 2 inches in diameter. 'The present holders up to dato havo crushed 240 tons from this part for a vield of $1160 z$. $15 d w t .12 \mathrm{gr}$. , the results obtained from the reef itsclf gave $1 \frac{1}{2} 0 z$. to $20 \%$. 5 dwt. per ton. "Ihis reuf at a higher berol yielded up to 15 ounces per tou.

As there is nearly 300 feet of slate from tho eentre, it is quite possible that it will continue for a similar distance north ( 80 feet above level, a cross-cnt has been driven 25 fect north from tho reef and shows no decrease it gold nor widtll of stone) probably thoso spurs will contime northward for many feet, and may intersect another recf. The ocenrenec of auriferous spurs and threads is an important discovery, so far as this district is concernel. From what I can ascertain, attention seems to have been directed to the reefis only. It is very probable that similar oceurrences have been overlooked in the earlier days. It is hardly possible to believe that gold oxists in these threads until the rock is broken and the quartz face exposed. 


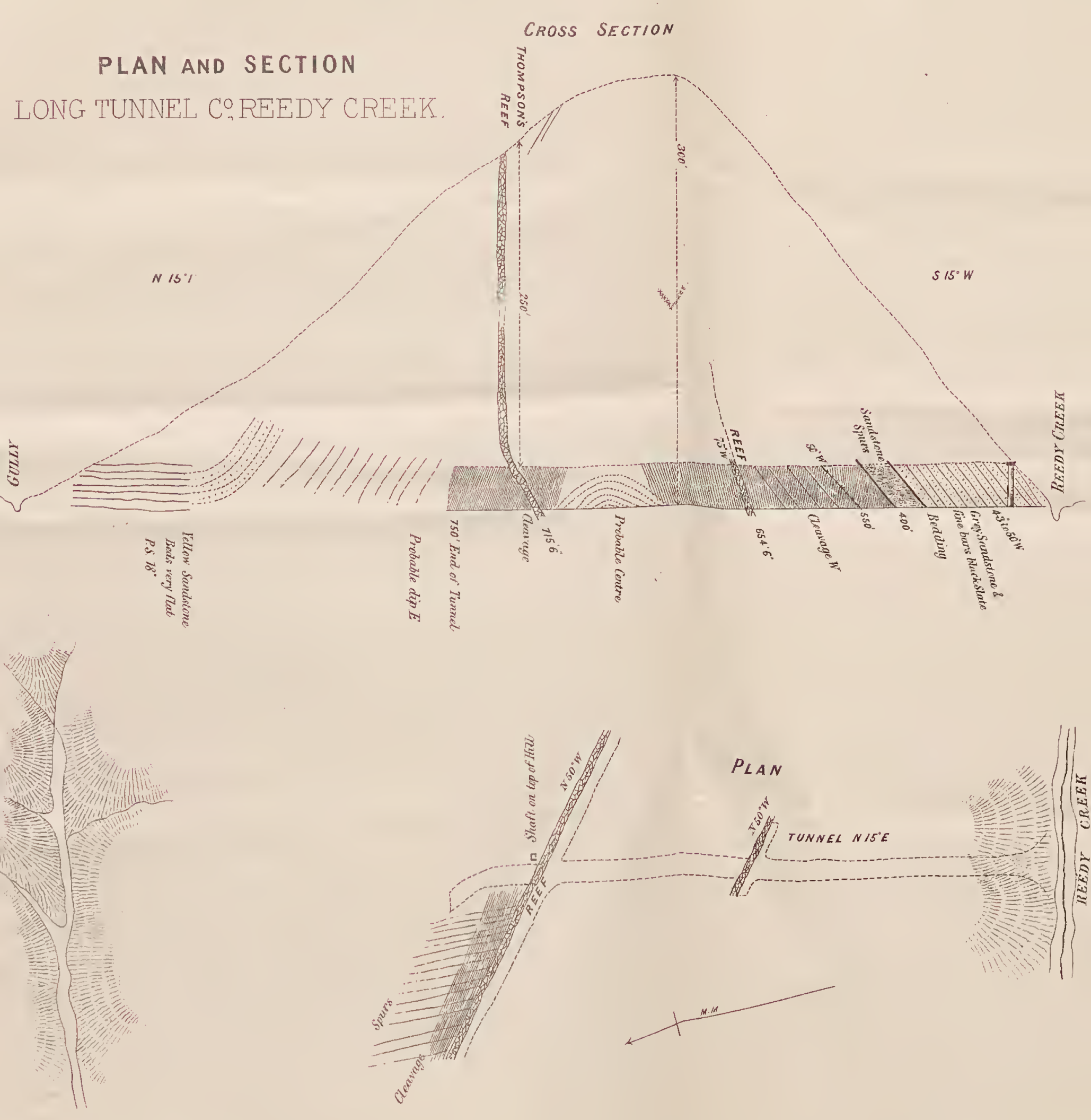


$$
\begin{aligned}
& p 559.455 \\
& v 642.1 t
\end{aligned}
$$

